Proc. Estonian Acad. Sci. Biol. Ecol., 2005, 54, 1, 18-39

\title{
Seasonality of zoo- and phytoplankton in Lake Peipsi (Estonia) as a function of water temperature
}

\begin{abstract}
Reet Laugaste ${ }^{*}$ and Juta Haberman
Võrtsjärv Limnological Station, Institute of Zoology and Botany, Estonian Agricultural University, 61101 Rannu, Tartumaa, Estonia; juta@ zbi.ee

Received 11 October 2004, in revised form 30 November 2004

Abstract. Seasonal variability of phyto- and zooplankton and water temperature was monitored in large moderately eutrophic Lake Peipsi using monthly sampling in the vegetation periods of 1997-2003. The dynamics of the fraction of small phytoplankton, edible for zooplankton (diameter up to $40 \mu \mathrm{m}$ ), was collated with that of the grazers of algae such as copepods and cladocerans. The main conclusions from this study are the following. The years of low temperatures coincide with the low biomass of cyanobacteria and cladocerans; the years of high temperatures coincide with their high biomass. The synergistic effect of low water level and high temperature can induce heavy water blooms caused by cyanobacteria. The autumn of the previous year seems to have an effect on the phytoplankton composition and biomass. Diatoms and, to a smaller extent, also cryptophytes and chlorophytes tend to ignore temperature. Cladocerans are more influenced by temperature than copepods and rotifers. The biomass of copepods and, to a smaller extent, of cladocerans changes commonly in parallel with the biomass of small algae in spring and late autumn (October-November) and in an opposite mode in summer and early autumn. The suppressing impact of cyanobacteria is only obvious in the case of very heavy water blooms. Water temperature has a stronger effect on zooplankton (particularly on cladocerans) in spring than in autumn. Water temperature is largely responsible for the variability of zoo- and phytoplankton.
\end{abstract}

Key words: phytoplankton and zooplankton seasonal dynamics, water temperature, large shallow lake.

\section{INTRODUCTION}

The grazing relationships between zoo- and phytoplankton are considered to be a controlling factor of the species composition and biomass of both planktonic algae and zooplankton. The existence of top-down control in plankton has been

*Corresponding author, reet@zbi.ee 
confirmed in many laboratory and biomanipulation experiments. In natural conditions the opposite dynamics of zoo- and phytoplankton is also pointed out by several authors (Gophen, 2003; Sommer, 1989). Sommer (1989) stressed the coinciding of midseason phytoplankton minima with peaks of zooplankton abundance and, presumably, grazing pressure. However, this cannot always prove the existence of direct relationships between these groups. In some lakes the abundance of small algae can be controlled largely by ciliate grazing (Muylaert et al., 2002). The feeding experiments carried out using fluorescent microspheres proved that ciliates are more important consumers of picoalgae than larger metazooplankters in strongly eutrophic Lake Võrtsjärv (Zingel, 2003). At the same time, the ciliate Nassula sp. was found to feed only on filamentous bluegreens in L. Võrtsjärv (Zingel, 2003). On the other hand, there is plenty of evidence that planktonic ciliates are an important food resource for large metazoan plankton (Carrick et al., 1991; Taylor \& Johannson, 1991; Wickham \& Gilbert, 1993).

The main criterion for the suitability of a food for zooplankton is evidently the size of food particles, which should be up to $30-40 \mu \mathrm{m}$ in diameter. Nowadays researchers suggest that zooplankters do not filter water in the sense of sieving, but particles of food are captured selectively (Wetzel \& Likens, 1991; Jensen \& Larsson, 2000). According to Nauwerck (1963), in L. Erken zooplankton preferred to eat small chrysophytes and cryptophytes, while small green algae with a thick cellulose shell were consumed in markedly smaller amounts. Nutrient limitation of green algae influences their cell walls, making them thicker, which probably reduces their digestibility, especially in P-limited cells (Ahlgren et al., 2000). In the absence of favourable food objects, zooplankters are able to feed on small cyanobacteria (Gulati et al., 2001) and even to split large colonies (Kryuchkova, 1989). Hence, by merely following the dynamics of total zoo- and phytoplankton, we cannot get an adequate picture about their trophic relations. It should be borne in mind that the pattern of seasonal dynamics is the result of many different factors combined.

The grazing efficiency of filtrative zooplankton depends largely on the weight of grazers. The larger the grazers, the more efficient is grazing (Sartonov, 1995; Meijer et al., 1999). The food ration is in direct correlation with the mean zooplankter weight. Daphnids are known to be effective grazers; frequently their maxima coincide with clear-water phases in a water body (Kuupo-Leinikki et al., 1994; Jürgens \& Stolpe, 1995). High grazing efficiency (50\% of phytoplankton production) in L. Peipsi is caused by the domination of efficient filtrators Daphnia galeata Sars, Bosmina berolinensis Imhof, and Eudiaptomus gracilis (Sars) in the lake (Haberman, 2001). The species of the genus Daphnia, which have a broad food spectrum, are considered powerful filtrators (Jeppesen et al., 1999; Boersma \& Stelzer, 2000). Burns (1968) found that large-bodied Daphnia species can filtrate round-shaped algae with a diameter of up to $80 \mu \mathrm{m}$.

The mean zooplankter weight $\left(\mathrm{W}_{\mathrm{ZP}}\right)$ is largely shaped by the trophic state of the water body. In moderately trophic Lake Peipsi, $\mathrm{W}_{\mathrm{ZP}}$ is $4.4 \mu \mathrm{g}$, in strongly eutrophic L. Võrtsjärv, $2.7 \mu \mathrm{g}$, in eutrophic Danish lakes $1.5 \mu \mathrm{g}$, and in oligo-mesotrophic L. Ladoga, 10-15 $\mu \mathrm{g}$ (Ogorodnikova, 1995; Jeppesen et al., 2000; Haberman \& 
Künnap, 2002). In moderately eutrophic Lake Peipsi the biomass is dominated by large, mostly herbivorous, zooplankters Daphnia galeata, D. cucullata Sars, Bosmina berolinensis, Limnosida frontosa Sars, Eudiaptomus gracilis a.o. The mean individual fresh weight of cladocerans in the vegetative period (MayOctober) is $28 \mu \mathrm{g}$ in L. Peipsi and $8.4 \mu \mathrm{g}$ in L. Võrtsjärv (Haberman \& Künnap, 2002). The mean weight of Daphnia $(54 \mu \mathrm{g})$ is determined mainly by the dominance of D. galeata (up to $\left.80 \mu \mathrm{g} \mathrm{ind}^{-1}\right)$, D. cucullata $\left(40-50 \mu \mathrm{g} \mathrm{ind}^{-1}\right.$ ), and D. cristata $\left(30-40 \mu \mathrm{g} \mathrm{ind}^{-1}\right)$. The mean weight of Bosmina $(21 \mu \mathrm{g})$ is determined by the large B. berolinensis $\left(54 \mu \mathrm{g}_{\text {ind }}^{-1}\right.$ ) (Haberman \& Nõges, 2003). The share of edible algae in phytoplankton biomass constitutes about $20 \%$ of total biomass in different seasons in L. Peipsi but only about $10 \%$ in L. Võrtsjärv (Nõges et al., 1998).

The relationships between zoo- and phytoplankton depend on the trophic state of lakes: direct relationships occur in oligo- and mesotrophic lakes, while microbial, detrital, and ciliate links are more important at higher trophic levels, which makes trophic relations more complicated. The zooplankton to phytoplankton biomass ratio $\left(\mathrm{B}_{\mathrm{Zp}} / \mathrm{B}_{\text {Phyt }}\right)$ has even been considered a highly informative index of eutrophication processes (Avinski et al., 1995). In L. Peipsi this ratio was the largest for the northern moderately eutrophic part, diminished southwards, and was the smallest for the strongly eutrophic southern part, L. Pihkva (Pskov). The average values of $\mathrm{B}_{\mathrm{Zp}} / \mathrm{B}_{\text {Phyt }}$ are lower than 0.5 for all lake parts $(0.49,0.30$, and 0.14 for the northern, middle, and southern parts, respectively). The highest values (about 2-3) occurred commonly for the northern part in June and slightly lower values (1-2) in May (Haberman \& Laugaste, 2003).

As compared with the lakes of low trophic state, in a highly eutrophic lake abiotic factors play a more important role, e.g. a decrease in zooplankton in midsummer can be caused by water turbidity and lack of oxygen but not by food availability (Makartseva \& Trifonova, 1991). Eutrophication causes an increase in the proportion of inedible algae. The amount of edible algae is the most significant environmental factor affecting zooplankton (George, 2000). At higher phosphorus levels the algal community often shifts to larger blue-green algae, and some species can be toxic for humans and animals (Moore et al., 2003).

Top-down control is also different in turbid and clear-water lakes: in clearwater lakes daphnids control phytoplankton in spring but not in summer; in turbid lakes the dominating Bosmina and cyclopoid copepods are relatively inefficient in suppressing phytoplankton biomass (Muylaert et al., 2002). In turbid lakes high grazing pressure to small algae is characteristic in spring but shifts to large algae in summer. Kirk \& Gilbert (1990), Telesh (1995), and Wolfinbarger (1999) found that high turbidity suppresses cladocerans but is favourable for rotifers. According to Sarvala et al. (2000), roughly one-third of the total variation of planktonic chlorophyll can be attributed to changes in zooplankton biomass, and another third to phosphorus concentration. Selective grazing by herbivorous zooplankton can be the major factor affecting the structure of the phytoplankton community in the littoral zones of several lakes, overriding even the effects of nutrient concentration (Lemly \& Dimmick, 1982). 
Besides mutual relationships, the dynamics of zoo- and phytoplankton is influenced by weather conditions, which affect differently different algal and zooplankton groups. Water level can affect phytoplankton through an increase in the internal nutrient loading in the low-water period (Padisák \& Koncsos, 2002); high temperatures favour growth of several zooplankters and promote cyanobacterial blooms. Summarizing the results of 37 Danish lakes, Jensen et al. (2002) considered phosphorus, water temperature, and mean depth the main components of the seasonal factor for phytoplankton, as well as cladocerans and copepods. When water temperature is the determining factor for phytoplankton growth in spring, then nutrients play the same role in summer (Schweizer, 1997).

Within the present investigation period, some years were quite exceptional with respect to water level and temperature: the autumn months (OctoberNovember) of the year 2000 were extraordinarily warm with a cyanobacterial water bloom; in 2002 the vegetation period was longer, beginning in mid-April, and the water level in summer was the lowest of 40 years with a heavy water bloom and fish kill in August.

The present study is focused on the seasonal dynamics of phyto- and zooplankton in L. Peipsi. The aim was to compare the dynamics of the fraction of small phytoplankton, edible for zooplankton (up to $40 \mu \mathrm{m} \mathrm{d}$ ), with that of the grazers of algae such as copepods and cladocerans in years with different weather conditions.

\section{STUDY SITE}

Lake Peipsi s.l. (3558 $\mathrm{km}^{2}$, mean depth $7.1 \mathrm{~m}$, total phosphorus concentration $\left(\mathrm{P}_{\mathrm{tot}}\right) 46.5 \mathrm{mg} \mathrm{m}^{-3}$, total nitrogen concentration $\left(\mathrm{N}_{\mathrm{tot}}\right) 687 \mathrm{mg} \mathrm{m}^{-3}$ as an average for the vegetation period of 1998-2002), located in eastern Estonia, on the border of Estonia and Russia, consists of three parts with a different trophic state each: moderately eutrophic clear-water L. Peipsi s.s., highly eutrophic L. Pihkva (Pskov), and narrow L. Lämmijärv connecting the former two parts. The present paper deals mainly with L. Peipsi s.s.; L. Pihkva is situated in the borders of Russia and the material from this lake was not available, with just a few exceptions. The whole lake is well mixed by the wind; there is no stratification of temperature, $\mathrm{O}_{2}$, and hydrochemical parameters in the ice-free period.

Diatoms predominate in the phytoplankton biomass in spring and autumn, in some years also in summer. Besides the large filamental forms of Aulacoseira islandica (O. Müller) Sim., A. granulata (Ehr.) Sim., and Stephanodiscus binderanus (Kütz.) Krieger, unicellular centric species (genera Cyclotella, Stephanodiscus, Cyclostephanos) and, to a smaller extent, Asterionella formosa Hass., are abundant as well. Cyanobacteria yield the highest biomass in summer and autumn. A summer cyanobacterial bloom occurs every year, even when the weather is cool. The most conspicuous forms are Gloeotrichia echinulata (J. S. Smith) P. Richter in summer in L. Peipsi s.s. and Aphanizomenon flos-aquae (L.) Ralfs in autumn in the southern parts. The genera of Microcystis and Anabaena are also of importance. 
The taxa that make up $20 \%$ or more of the total abundance and biomass of zooplankton are considered the dominants. Along with the character species of oligo-mesotrophic waters (Conochilus hippocrepis (Schrank), C. unicornis Rousselet, Kellicottia longispina Kellicott, and Bosmina berolinensis), the dominants of L. Peipsi include also species preferring eutrophic waters (Keratella cochlearis (Gosse), Daphnia cucullata, Bosmina c. coregoni Baird; sometimes, with respect to numbers, even Anuraeopsis fissa (Gosse) and Keratella tecta (Gosse)) are dominants. The most important dominating zooplankters with respect to biomass are effective grazers of small algae: the calanoid Eudiaptomus gracilis and species of the genera Daphnia (D. cucullata, D. cristata Sars, D. galeata) and Bosmina (B. berolinensis, B. gibbera Schoedler, B. c. coregoni). In zooplankton abundance rotifers prevail throughout the year (on average 74\%); in biomass they prevail under the ice cover and in single cases in the vegetation period. Mass development of cladocerans starts in June when they make up about $30 \%$ of the biomass; they dominate in biomass in July (mainly the genus Daphnia) and account for about $50 \%$ of the biomass in the autumn months (genus Bosmina). Copepods, particularly Eudiaptomus gracilis and species of the genus Mesocyclops, form about $35 \%$ of the biomass during the whole year. The dynamics of zooplankton biomass is similar to that of water temperature, with a peak usually in midsummer. Also the biomass of herbivorous zooplankton has commonly a maximum in the summer months (June-August).

\section{MATERIAL AND METHODS}

The basic material was collected monthly from the pelagial of the Estonian part of L. Peipsi (5-6 sampling sites) in the vegetation periods of 1997-2003. The samples from 15 stations over the whole area of the lake, including the southern part, L. Pihkva, were picked in August 2003. The methods of collecting and treating samples are described in detail in Laugaste et al. (2001) and in Haberman (2001). The hydrochemical samples were analysed in Tartu Environmental Researchers Ltd, Estonia, the data of water temperatures (daily temperatures to calculate the monthly average for correlation analysis) and water level were obtained from the Institute of Meteorology and Hydrology. Spearman correlation analysis (STATISTICS for Windows) was used for evaluating some abiotic and biotic characteristics of the lake.

\section{RESULTS}

Table 1 presents the data on zooplankton and phytoplankton for the study period. Next we follow the water temperature and the dynamics of plankton groups for the same period (Fig. 1). 
Table 1. Seasonal dynamics of zooplankton and phytoplankton, average values of 1997-2003. Abbreviations: WT - water temperature at sampling, Zp - zooplankton, bm - biomass, ab - abundance, Rot-rotifers, Clad-cladocerans, Cop-copepods, D. gal-Daphnia galeata, D. cuc-D. cucullata, Eudiapt-Eudiaptomus, Phyto - phytoplankton, Cy-cyanobacteria, Bac-diatoms, Chl - chlorophytes, Chr - chrysophytes, Cryp - cryptophytes, small algae - algae with diameter $<40 \mu \mathrm{m}$, Avg - arithmetical mean

\begin{tabular}{|c|c|c|c|c|c|c|c|}
\hline Month & $\begin{array}{l}\text { WT, } \\
{ }^{\circ} \mathrm{C}\end{array}$ & $\begin{array}{c}\mathrm{Zp} \mathrm{bm} \\
\mathrm{g} \mathrm{m}^{-3}\end{array}$ & $\begin{array}{c}\mathrm{Zp} \mathrm{ab}, \\
10^{3} \text { ind. } \mathrm{m}^{-3}\end{array}$ & $\begin{array}{c}\text { Rot bm, } \\
\mathrm{g} \mathrm{m}^{-3}\end{array}$ & $\begin{array}{c}\text { Rot ab, } \\
10^{3} \text { ind. } \mathrm{m}^{-3}\end{array}$ & $\begin{array}{c}\text { Clad bm, } \\
\mathrm{g} \mathrm{m}^{-3}\end{array}$ & $\begin{array}{l}\text { Clad ab, } \\
10^{3} \text { ind. } \mathrm{m}^{-3}\end{array}$ \\
\hline May & 9.5 & 1.259 & 698.6 & 0.376 & 565.9 & 0.135 & 7.8 \\
\hline June & 16.0 & 2.190 & 696.9 & 0.486 & 527.2 & 0.802 & 30.8 \\
\hline July & 19.9 & 2.459 & 577.4 & 0.219 & 363.8 & 1.492 & 43.1 \\
\hline Aug & 19.5 & 2.037 & 579.0 & 0.605 & 404.6 & 0.850 & 41.9 \\
\hline Sep & 14.6 & 1.537 & 435.3 & 0.207 & 320.1 & 0.668 & 32.7 \\
\hline Oct & 9.5 & 0.911 & 249.4 & 0.130 & 190.6 & 0.419 & 27.8 \\
\hline Nov & 4.3 & 0.580 & 127.3 & 0.139 & 100.7 & 0.242 & 12.2 \\
\hline Avg & 13.7 & 1.60 & 491.5 & 0.318 & 298.3 & 0.674 & 30.8 \\
\hline Median & 14.4 & 1.16 & 293.0 & 0.118 & 114.8 & 0.391 & 18.0 \\
\hline SD & 5.6 & 1.44 & 508.7 & 0.558 & 430.0 & 0.901 & 52.2 \\
\hline Month & $\begin{array}{c}\text { Cop bm, } \\
\mathrm{g} \mathrm{m}^{-3}\end{array}$ & $\begin{array}{c}\text { Cop ab, } \\
10^{3} \text { ind. } \mathrm{m}^{-3}\end{array}$ & $\begin{array}{l}\text { D. gal, } \\
\mathrm{g} \mathrm{m}^{-3}\end{array}$ & $\begin{array}{l}\text { D. cuc, } \\
\mathrm{g} \mathrm{m}^{-3}\end{array}$ & $\begin{array}{l}\text { Daphnia, } \\
\mathrm{g} \mathrm{m}^{-3}\end{array}$ & $\begin{array}{l}\text { Bosmina } \\
\mathrm{g} \mathrm{m}^{-3}\end{array}$ & $\begin{array}{l}\text { Eudiapt, } \\
\mathrm{g} \mathrm{m}^{-3}\end{array}$ \\
\hline May & 0.748 & 125.0 & 0.036 & 0.004 & 0.042 & 0.087 & 0.073 \\
\hline June & 0.887 & 138.1 & 0.132 & 0.166 & 0.436 & 0.506 & 0.142 \\
\hline July & 0.679 & 127.3 & 0.148 & 0.583 & 1.011 & 0.096 & 0.152 \\
\hline Aug & 0.569 & 110.9 & 0.151 & 0.184 & 0.365 & 0.086 & 0.172 \\
\hline Sep & 0.659 & 81.9 & 0.146 & 0.198 & 0.379 & 0.232 & 0.245 \\
\hline Oct & 0.362 & 31.0 & 0.050 & 0.019 & 0.071 & 0.260 & 0.201 \\
\hline Nov & 0.199 & 14.4 & 0.036 & 0.001 & 0.037 & 0.191 & 0.116 \\
\hline Avg & 0.596 & 78.4 & 0.118 & 0.183 & 0.360 & 0.210 & 0.159 \\
\hline Median & 0.457 & 51.0 & 0.000 & 0.000 & 0.043 & 0.079 & 0.096 \\
\hline SD & 0.579 & 81.5 & 0.323 & 0.616 & 0.808 & 0.599 & 0.202 \\
\hline Month & $\begin{array}{c}\text { Phyto bm, } \\
\mathrm{g} \mathrm{m}^{-3}\end{array}$ & $\begin{array}{c}\text { Cy bm, } \\
\mathrm{g} \mathrm{m}^{-3}\end{array}$ & $\begin{array}{c}\mathrm{Bac} \mathrm{bm}, \\
\mathrm{g} \mathrm{m}^{-3}\end{array}$ & $\begin{array}{c}\text { Chl bm, } \\
\mathrm{g} \mathrm{m}^{-3}\end{array}$ & $\begin{array}{c}\text { Chr bm, } \\
\mathrm{g} \mathrm{m}^{-3}\end{array}$ & $\begin{array}{c}\text { Cryp bm, } \\
\mathrm{g} \mathrm{m}^{-3}\end{array}$ & \begin{tabular}{|c|} 
Small algae, \\
$\mathrm{g} \mathrm{m}^{-3}$
\end{tabular} \\
\hline May & 5.688 & 0.447 & 4.444 & 0.131 & 0.140 & 0.359 & 1.169 \\
\hline June & 6.106 & 3.225 & 2.002 & 0.162 & 0.044 & 0.554 & 0.936 \\
\hline July & 9.200 & 5.686 & 2.340 & 0.224 & 0.021 & 0.572 & 0.925 \\
\hline Aug & 11.926 & 6.992 & 4.020 & 0.211 & 0.015 & 0.196 & 0.577 \\
\hline Sep & 10.945 & 6.052 & 4.155 & 0.271 & 0.013 & 0.237 & 0.643 \\
\hline Oct & 8.993 & 3.327 & 5.082 & 0.264 & 0.011 & 0.147 & 0.549 \\
\hline Nov & 12.027 & 2.469 & 9.021 & 0.225 & 0.006 & 0.101 & 0.429 \\
\hline Avg & 8.492 & 3.700 & 4.424 & 0.197 & 0.038 & 0.298 & 0.748 \\
\hline Median & 7.132 & 2.225 & 2.728 & 0.150 & 0.009 & 0.165 & 0.546 \\
\hline SD & 6.475 & 4.939 & 5.049 & 0.183 & 0.087 & 0.457 & 0.641 \\
\hline
\end{tabular}




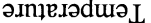

กำ

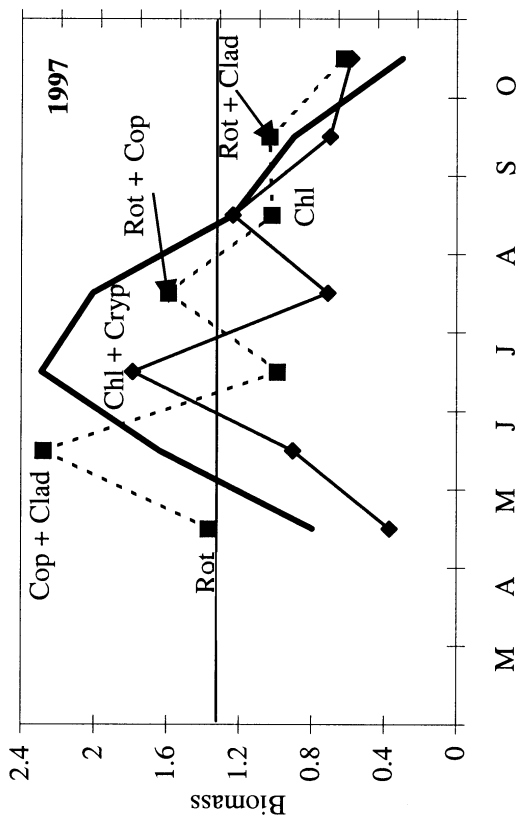

ว.กฺฺเวdนว

สำ느는

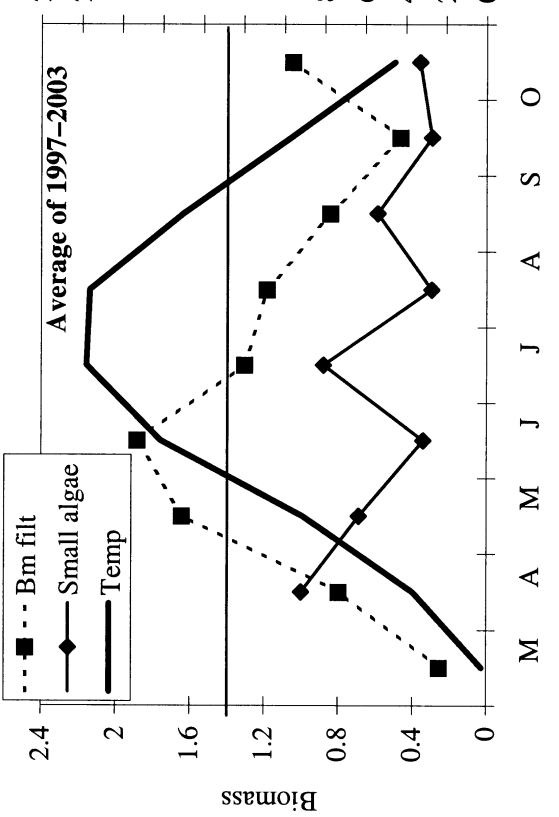

ฐ

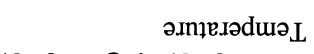

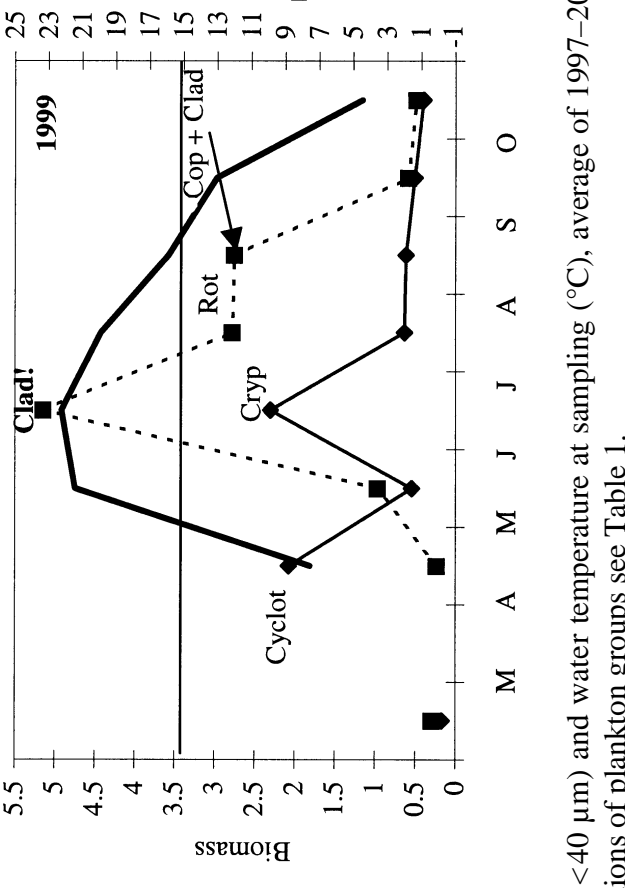

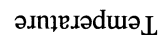

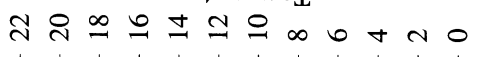

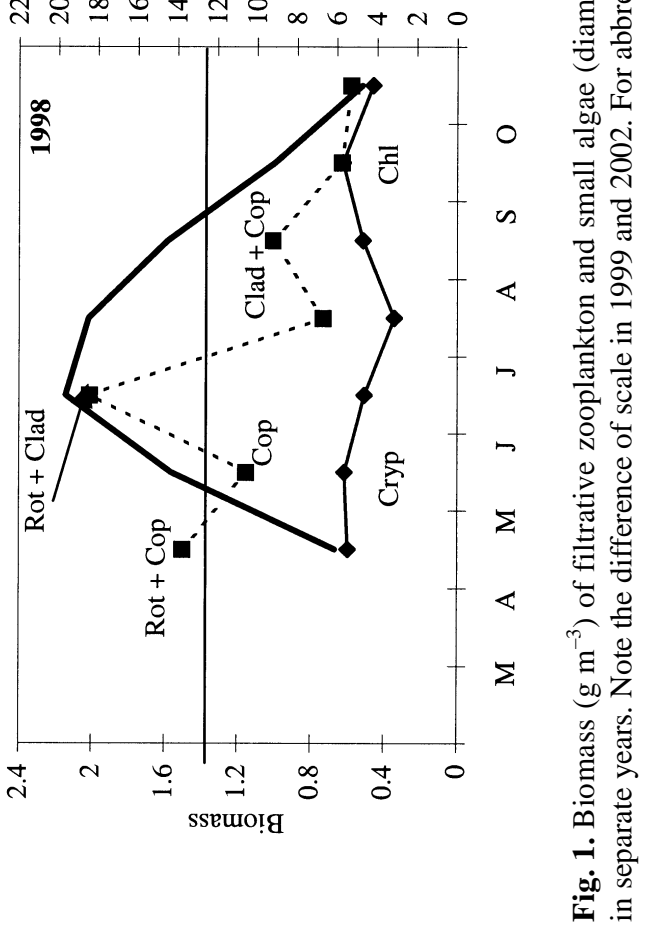


วInฺฺวdนวL

ส유 $\infty \pm \pm ㅇ$

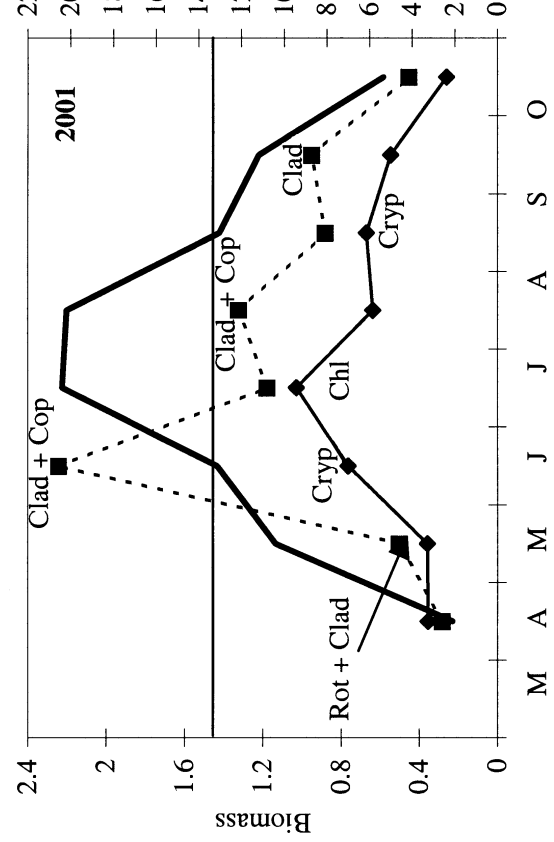

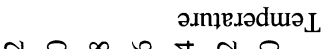

กㅇำ느는

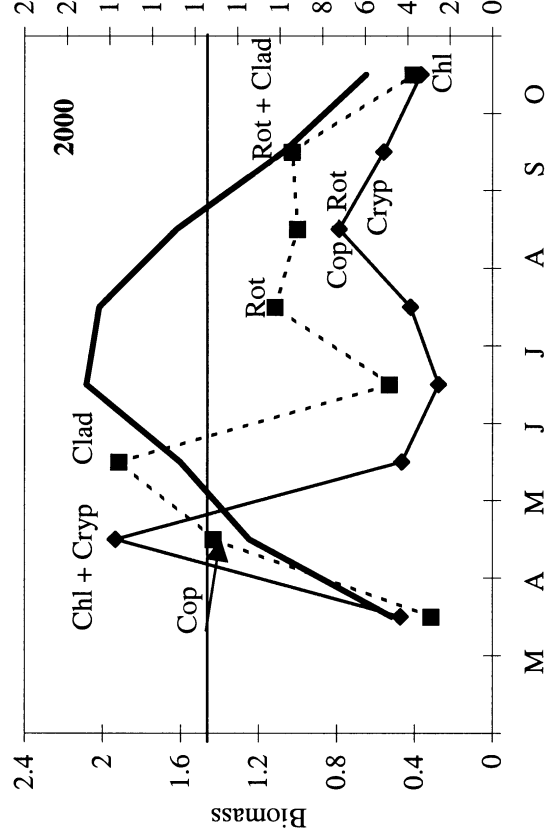

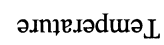

กำำำ의

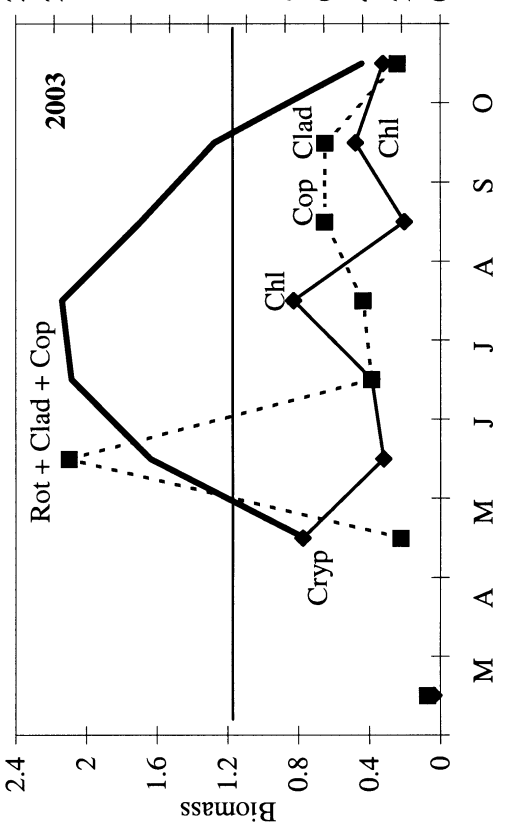

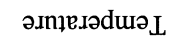

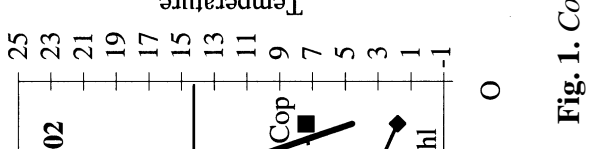

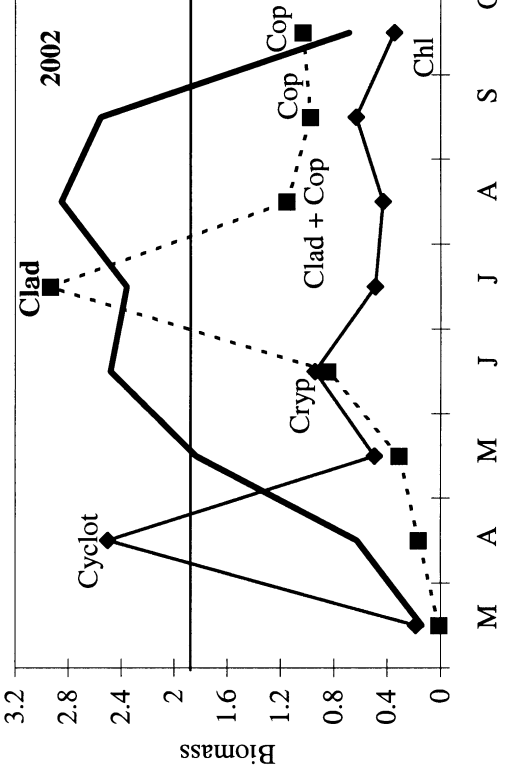


The year 1997 with a relatively cool spring, warm July, and cool autumn was characterized by a low biomass of cyanobacteria and high levels of cryptophytes and zooplankton abundance. In May (water temperature $6{ }^{\circ} \mathrm{C}$ ), rotifers attained their maximum biomass as large winter species (Polyarthra dolichoptera Idelson, Synchaeta verrucosa Nipkow) were still prevailing at that time. Phytoplankton biomass was very low in spring. In October-November 1996, with a low water level, a heavy cyanobacterial bloom, not common in late autumn, was observed. The absence of a spring peak of diatoms was uncommon as well - it occurred for the first time during our seasonal studies since 1963. In June peaks of cladocerans (genus Bosmina accounting for $45 \%$ of the total zooplankton biomass, and B. berolinensis for $32 \%$ ) and copepods (filtrative forms accounting for $22 \%$ of the zooplankton biomass) took place with the increasing biomass of their food objects - chlorophytes and cryptophytes (small algae). Both attained their maximum in July when the biomass of all zooplankton groups decreased. The next, smaller peak of small algae occurred in September with the abrupt decrease in the biomass of copepods (mainly Eudiaptomus gracilis). The feeding of E. gracilis is highly selective: it prefers small algae and cannot feed on bacteria (Lampert, 1992). As it feeds on small algae, this species is regarded as an inhabitant of mostly oligo- and mesotrophic waters (Muck \& Lampert, 1984). The domination of E. gracilis in L. Peipsi reflects the moderate trophic state of the lake.

The year 1998 was characterized by a cold spring, a relatively cool summer, and a high water level in autumn. The biomass of phytoplankton and zooplankton groups was low except for diatoms and rotifers whose biomass was moderate. The peak of rotifers and copepods was observed in May. Cryptophytes attained their peak in June (only one-third of the peak registered in July 1997). The biomass of small algae was quite low during the vegetation period. It was remarkable that the biomass of chlorophytes increased continuously from May to November but remained on a quite low level throughout the vegetation period.

The year 1999 was warm and dry, especially the summer months (June-August). The water level was extraordinarily high in spring but relatively low in autumn. It was a high-yield year of Aulacoseira islandica, recorded in L. Peipsi about twice per decade relatively irrespective of weather conditions. In spite of the very warm summer, the biomass of blue-green algae was quite low. The average values for the vegetation period were extraordinarily high for cryptophytes and high for zooplankton groups, particularly cladocerans. Small algae had peaks in May (Cyclotella) and somewhat higher peaks in July (cryptophytes), accompanied with the highest biomass of cladocerans in summer. The biomass of small algae started to decrease in August, and was about five times lower during the second peak of cladocerans and copepods in September than in July. High summer temperatures, particularly in July, could cause the highest biomass of cladocerans for the seven study years. The biomass of cladocerans, formed of daphnids (D. cristata accounting for $30 \%$ of the total zooplankton biomass and $44 \%$ of the cladoceran biomass), reached $5.085 \mathrm{~g} \mathrm{~m}^{-3}$ in July. The bloom of A. islandica in 
October-November had no evident suppressive effect on the other algal and zooplankton groups.

The year $\mathbf{2 0 0 0}$ was characterized by a quite warm spring, a relatively cool and cloudy summer, and extraordinarily warm autumn months. This brought about an increasing biomass of blue-green algae and an Aphanizomenon bloom in OctoberNovember, while the autumn peak of diatoms was lacking, having been replaced by a summer peak in August. The zooplankton biomass was the highest in MayJune, dominated by copepodids of the genus Mesocyclops in May, and Daphnia spp. in June; copepods occurred simultaneously with peaks of Cyclotella and chlorophytes in May, and cladocerans coexisted with cryptophytes in June. The very low biomass of cladocerans and copepods in autumn was evidently related to a cyanobacterial bloom lasting until late November. The year was distinguished by the low biomass of chlorophytes, very high zooplankton abundance in summer (rotifers, Dreissena polymorpha Pallas juv.), and a high biomass of copepods in May.

The year 2001 had a warm summer. The biomass of diatoms, cryptophytes, and cladocerans was low. During 40 studied years, A. islandica was absent from spring and autumn plankton for the first time. It was replaced by the more eutrophic A. ambigua (Grun.) Simonsen, which attained its peak in June and August. This alga has been quite common in L. Peipsi but has never belonged among the dominants. The peaks of all zooplankton groups as well as of chlorophytes were registered in June (zooplankton biomass reached $4.415 \mathrm{~g} \mathrm{~m}^{-3}$ ), while a peak of small algae (cryptophytes and a smaller peak of chlorophytes) occurred in July when zooplankton decreased (biomass $1.648 \mathrm{~g} \mathrm{~m}^{-3}$ ). The biomass of cyanobacteria increased towards the autumn but remained markedly lower than in the previous year. The patterns of the biomass of zooplankton and cyanobacteria were very clearly opposite from May to November. Commonly these courses are parallel, both groups depending positively on temperature. Smith \& Gilbert (1995) claim that the toxins of cyanobacteria, which dominate in strongly eutrophic waters (Microcystis aeruginosa Kütz. emend Elenk.), suppress the growth of cladocerans. Especially sensitive to these toxins is the effective grazer Eudiaptomus gracilis (DeMott \& Moxter, 1991).

The year $\mathbf{2 0 0 2}$ had an early spring, the vegetation period began about a month earlier than usual. The spring peak of phytoplankton occurred in April, and the clear water period was in May instead of June. Water was very warm from June to September but cold in October-November. Water level was especially low in August and also in autumn. The biomass of diatoms, chlorophytes, and rotifers was low throughout the vegetation period. The bloom of cyanobacteria began already in June, lasted until September, and had a very high peak in August (caused by Gloeotrichia echinulata and Anabaena circinalis Rabenh.), accompanied with a severe fish kill. Zooplankton had the highest biomass in July (cladocerans accounting for $73 \%$ and D. cucullata for $51 \%$ of the zooplankton biomass), which followed a peak of cryptophytes and a smaller peak of chlorophytes in June. The zooplankton biomass decreased in August during the cyanobacterial bloom. An 
extraordinarily high peak of Cyclotella was observed in April after ice break when the growth of grazers had not yet started. A small spring peak of A. islandica was noted as well.

The year 2003 was characterized by moderate temperatures and low water level in autumn. Almost all groups of phyto- and zooplankton had low biomasses, with the exclusion of chlorophytes. A peak of all zooplankton groups was recorded in June (zooplankton biomass $2.012 \mathrm{~g} \mathrm{~m}^{-3}$ ), and a smaller peak of cladocerans in October and of copepods in September. A peak of small algae (mainly chrysophytes) was observed in August, while cryptophytes had three almost similar peaks - in May, August, and October. Phytoplankton biomass was quite low throughout the vegetation period, and zooplankton abundance was the lowest of the seven years studied. It is noteworthy that the abundance of small rotifers was incredibly low in July, August, and October. A possible explanation is the unusually large proportion of the semi-predator Asplanchna priodonta Gosse (accounting for $94 \%$ of the total zooplankton biomass in August). Intensive preying of A. priodonta on Keratella species and other small rotifers is well known. In July and October suppression of rotifers by cladocerans is likely: as cladocerans and rotifers are food rivals, then being larger and more powerful filtrators, cladocerans also suppress rotifers (Gilbert \& Stemberger, 1985; Dokulil et al., 1990). Frequently this effect is attributed to exploitative competition. Still, the idea that mechanical interference competition is an agent for the evolution of inverse relationships between the abundances of cladocerans and rotifers is gaining support. In this case, Keratella is swept into the branchial chamber of daphnids and is either killed, mortally wounded, or will loose the attached egg. Occasionally, Keratella can even be found in the gut of Daphnia. In Mondsee, K. cochlearis was found within the thicket of the filtering limbs of a number of Daphnia hyalina (Dokulil et al., 1990).

In August 2003 we succeeded in covering the whole lake's aquatory, including the Russian part of the lake, by sampling. Samples were collected from 15 sites. The biomass of cladocerans was 5-7 times higher and the biomass of copepods was about two times higher in the southern lake parts (Fig. 2) than in the northern part. At the same time, rotifers had insignificant biomasses in the southern parts as well as in the southeastern part of L. Peipsi s.s. The biomass of cyanobacteria (prevailing genus Microcystis) was distributed similarly to the biomass of cladocerans, while small algae (mainly chlorophytes) were most abundant in the central part of Peipsi s.s. and somewhat less abundant in L. Pihkva (mainly chlorophytes and small centric diatoms) and in the mouth of the Emajõgi River. The biomass of small centric diatoms was correlated with the biomass of Daphnia cucullata $(r=0.58, P=0.02)$, cladocerans $(r=0.60, P=0.019)$, and rotifers $(r=-0.65, P=0.009)$. The other groups of small algae (chlorophytes, cryptophytes, and chrysophytes) as well as the sum of their biomasses (incl. small centric diatoms) had only weak significant correlations with the zooplankton groups and with the filter-feeding genera (Daphnia, Bosmina, Chydorus, and Eudiaptomus). It is possible that the small number of rotifers in the southern lake parts was 


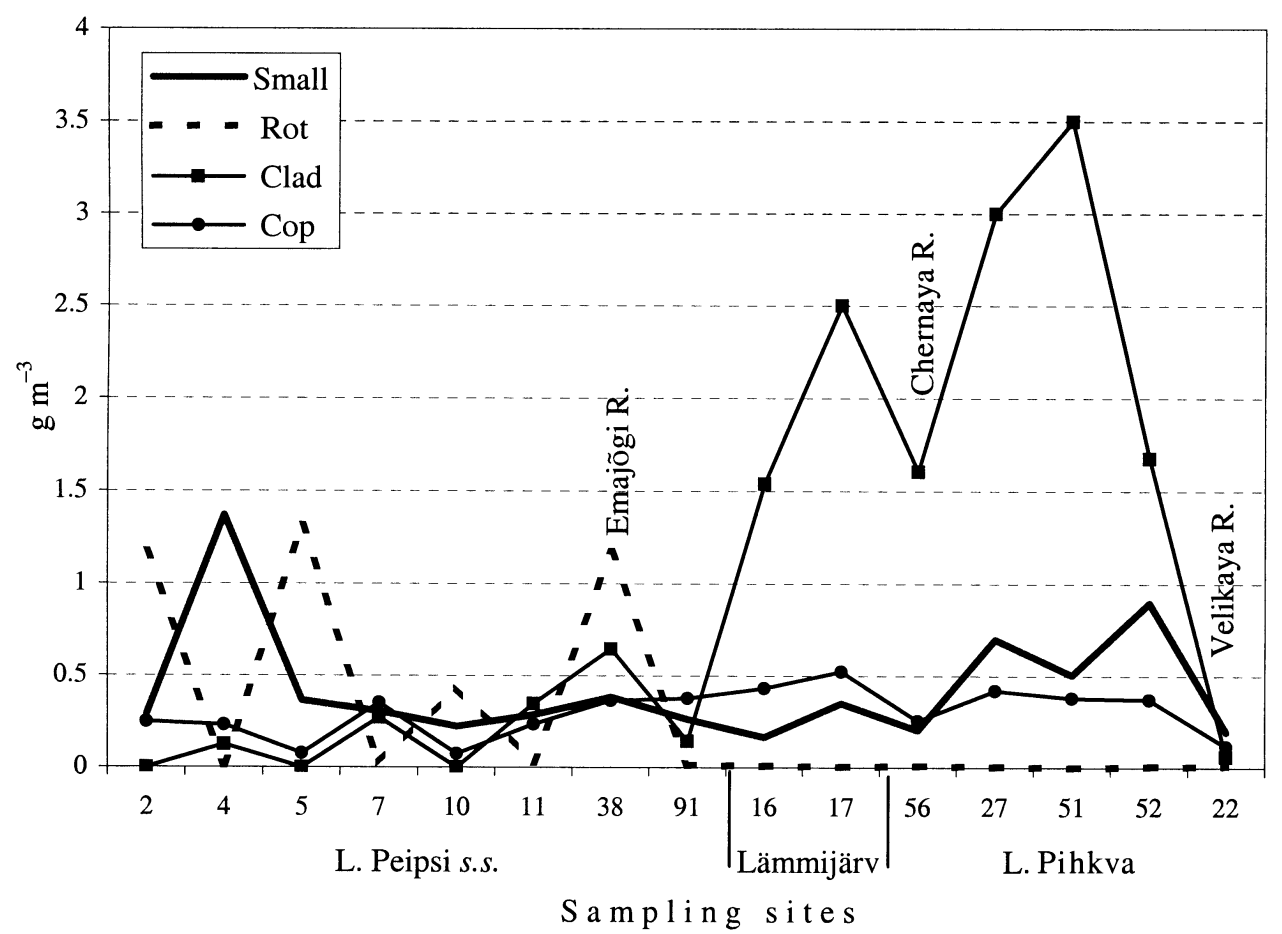

Fig. 2. Biomass of small algae and zooplankton groups in sampling sites in August 2003.

associated with the toxic effect of some blue-green algae. In August Microcystis viridis Lemm. was prevailing with a biomass of up to $20 \mathrm{~g} \mathrm{~m}^{-3}$, and microcystins were observed (see Tanner et al., 2005) in this area. The toxic effect of cyanobacteria on zooplankton groups, particularly on Daphnia, is noted by several authors, and susceptibility of planktonic rotifers to a toxic strain of Anabaena was stressed by Gilbert (1994). On the other hand, it is known that daphnids are able to consume soft forms of Microcystis aeruginosa and other cyanobacteria (Matveev \& Matveeva, 1997).

Some results of Spearman correlation analysis are presented in Tables 2 and 3. Diatoms and cyanobacteria have opposite correlations with temperature $(r=0.46$ for cyanobacteria, -0.38 for diatoms) and water level ( -0.27 for cyanobacteria and 0.22 for diatoms). Zooplankton groups and genera have significant positive correlations with temperature ( $r=0.70$ for the abundance of Dreissena, 0.61 for the abundance of cladocerans and copepods, and 0.60 for the abundance of zooplankton). Cladocerans and copepods are negatively and rotifers positively correlated with water level. Positive correlations of the zooplankton groups and genera with the biomass of phytoplankton and cyanobacteria are revealed through a similar effect of temperature. Diatoms do not display any correlation with zoo- 
plankton. Zooplankton groups and genera have significant moderate positive correlations with potential food objects (green algae and cryptophytes but not Cyclotella); the correlation is the strongest for Eudiaptomus gracilis $(r=0.44$ for chlorophytes and 0.42 for cryptophytes, Table 2). Negative correlations with chrysophytes can be due to the opposite behaviour of this group in comparison with the other algal groups, as well as to its opposite response to trophy. Rotifers are not correlated with phytoplankton (it is a well-known fact that rotifers feed mainly on bacteria). Water temperature in spring has a stronger effect on zooplankton than temperature in autumn and at the time of sampling (Table 3), while Daphnia and Bosmina species are particularly affected in this respect.

Table 2. Correlations between zoo- and phytoplankton $(P<0.01)$. The most notional correlations are in bold. Abbreviations: Cyclot - Cyclotella, Filtr - filtrators, Pred - predators, Dreis - Dreissena veliger, B. cor-Bosmina coregoni, Cycl filtr - filtrative cyclopoids, Chyd-Chydorus sphaericus. For other abbreviations see Table 1

\begin{tabular}{|c|c|c|c|c|c|c|c|c|c|}
\hline & $\begin{array}{l}\text { WT, } \\
{ }^{\circ} \mathrm{C}\end{array}$ & $\begin{array}{c}\text { Phyto } \\
\text { bm }\end{array}$ & $\begin{array}{l}\mathrm{Cy} \\
\mathrm{bm}\end{array}$ & $\begin{array}{l}\mathrm{Bac} \\
\mathrm{bm}\end{array}$ & $\begin{array}{l}\text { Chl } \\
\text { bm }\end{array}$ & $\begin{array}{l}\mathrm{Chr} \\
\mathrm{bm}\end{array}$ & $\begin{array}{c}\text { Cryp } \\
\text { bm }\end{array}$ & $\begin{array}{c}\text { Cyclot } \\
\text { bm }\end{array}$ & $\begin{array}{l}\text { Small } \\
\text { algae }\end{array}$ \\
\hline WT & & & 0.464 & -0.255 & & -0.305 & 0.371 & & 0.418 \\
\hline $\mathrm{Zp} \mathrm{ab}$ & 0.596 & -0.23 & 0.242 & & & 0.208 & 0.34 & & \\
\hline $\mathrm{Zp} \mathrm{bm}$ & 0.561 & & 0.38 & & 0.26 & & 0.22 & & 0.525 \\
\hline Filtr bm & 0.556 & & 0.399 & & 0.27 & & & & \\
\hline Pred bm & 0.388 & & & & & & & & \\
\hline Rot $a b$ & & & -0.369 & & & & & & \\
\hline \multicolumn{10}{|l|}{ Rot bm } \\
\hline Rot $a b \%$ & -0.44 & -0.203 & -0.272 & & -0.32 & 0.208 & & & -0.349 \\
\hline Clad ab & 0.344 & 0.292 & 0.4 & & 0.35 & -0.366 & & & \\
\hline Clad bm & 0.462 & 0.309 & 0.459 & & 0.372 & -0.299 & 0.39 & & 0.449 \\
\hline Clad ab\% & & 0.36 & 0.212 & & 0.397 & -0.203 & 0.398 & -0.267 & \\
\hline Cop ab & 0.607 & & 0.246 & & & -0.398 & 0.328 & & \\
\hline Cop bm & 0.459 & & 0.247 & & 0.33 & -0.348 & 0.38 & & 0.584 \\
\hline Cop ab\% & 0.518 & & -0.299 & & & & & & \\
\hline Dreis bm & 0.695 & 0.329 & 0.52 & & & -0.238 & & & \\
\hline Daphnia bm & 0.437 & 0.345 & 0.505 & & 0.32 & -0.21 & & & \\
\hline D. gal bm & & 0.295 & 0.389 & & 0.304 & & 0.384 & & \\
\hline D. $c u c$ bm & 0.524 & 0.344 & 0.489 & & 0.289 & -0.22 & 0.339 & & \\
\hline Bosmina bm & & & & & 0.246 & & 0.325 & & \\
\hline B. cor bm & & 0.235 & 0.24 & & & & 0.33 & & \\
\hline Eudiapt bm & & 0.234 & 0.372 & & 0.44 & -0.341 & 0.422 & & \\
\hline Cycl filtr & 0.439 & & & & & & 0.38 & & 0.552 \\
\hline Chyd bm & 0.44 & 0.35 & 0.331 & & 0.285 & -0.259 & & & \\
\hline
\end{tabular}


Table 3. Correlations of zooplankton parameters with spring and autumn temperature. Abbreviations as in Tables 1 and 2. B. berol-Bosmina berolinensis

\begin{tabular}{|c|c|c|c|c|}
\hline \multirow[t]{2}{*}{ Parameter } & \multicolumn{2}{|c|}{ Spring, $n=64$} & \multicolumn{2}{|c|}{ Autumn, $n=67$} \\
\hline & $r$ & $P$ & $r$ & $P$ \\
\hline Clad $a b \%$ & 0.7 & $<0.001$ & & \\
\hline Clad bm\% & 0.7 & $<0.001$ & & \\
\hline Cop ab\% & 0.25 & 0.04 & 0.32 & 0.01 \\
\hline Cop bm\% & 0.35 & 0.01 & & \\
\hline Rot $a b \%$ & 0.63 & $<0.001$ & & \\
\hline Rot bm\% & -0.48 & $<0.001$ & & \\
\hline Dreis $a b \%$ & 0.32 & 0.001 & & \\
\hline Dreis bm\% & 0.63 & $<0.001$ & & \\
\hline Clad ab & 0.51 & $<0.001$ & 0.44 & $<0.001$ \\
\hline Clad bm & 0.35 & 0.005 & 0.3 & 0.017 \\
\hline Cop ab & 0.24 & 0.05 & & \\
\hline Cop bm & 0.34 & 0.005 & 0.46 & $<0.001$ \\
\hline Rot ab & 0.63 & $<0.001$ & 0.74 & $<0.001$ \\
\hline Rot bm & 0.5 & $<0.001$ & & \\
\hline Dreis ab & 0.53 & $<0.001$ & & \\
\hline D. gal bm & 0.41 & 0.001 & & \\
\hline D. $c u c$ bm & 0.63 & $<0.001$ & 0.5 & $<0.001$ \\
\hline Daphnia bm & 0.62 & $<0.001$ & & \\
\hline Bosmina bm & 0.51 & $<0.001$ & & \\
\hline B. berol bm & 0.24 & 0.05 & -0.29 & 0.019 \\
\hline B. cor & 0.53 & $<0.001$ & & \\
\hline Eudiapt & 0.5 & $<0.001$ & & \\
\hline Limnosida & 0.35 & 0.005 & & \\
\hline Cycl filtr & 0.34 & 0.005 & 0.66 & $<0.001$ \\
\hline Chydorus & 0.41 & $<0.001$ & 0.39 & 0.001 \\
\hline Nauplii & & & 0.67 & $<0.001$ \\
\hline
\end{tabular}

\section{DISCUSSION}

The significant effect of water temperature on the zooplankton composition is well known (Beaver \& Havens, 1996; Beisner et al., 1996). Herzig (1994) noted that abiotic environmental factors (water temperature, wind, waves) influence zooplankton especially in spring and autumn, while the effect of biotic factors (food, predators) is usually more pronounced in summer. In L. Peipsi both the number and biomass of zooplankton are in a relatively strong positive correlation with water temperature $(r=0.5$ and $0.4 ; P<0.0001)$ (Haberman, 2001).

The effectiveness of zooplankters' feeding depends largely on water temperature and is the highest in summer - in July and August in L. Peipsi. The zooplankters' food ration and water temperature are in a fairly good correlation in L. Peipsi 
$(r=0.5 ; P<0.0001)$ (Haberman, 1996, 2001). In L. Balaton the abundance of Daphnia has a strong positive correlation with spring water temperature and a negative correlation with the chlorophyll content, while temperature (annual mean) and chlorophyll are not correlated (Carvalho \& Kirika, 2003). The global trend of warming affects winter and spring more than the other seasons. Warmer spring and autumn increase Daphnia densities. In L. Peipsi s.s. the very cold May $\left(6^{\circ} \mathrm{C}\right.$ at the time of sampling) and cool June $\left(14^{\circ} \mathrm{C}\right)$ of 1998 may have been the cause of the low biomass of Daphnia in June $\left(0.04 \mathrm{~g} \mathrm{~m}^{-3}\right)$, and the cold May $\left(7^{\circ} \mathrm{C}\right)$ and very warm June $\left(21^{\circ} \mathrm{C}\right)$ of 1999 may have caused the somewhat elevated biomass of Daphnia $\left(0.15 \mathrm{~g} \mathrm{~m}^{-3}\right)$ in June and its very high biomass in July (Fig. 1). Small algae (Cyclotella) had a relatively high maximum in May 1999 but did not reveal any obvious relationship with zooplankton. The extraordinarily early beginning of the vegetation period and the warm May and June in 2002 brought about a high peak of Cyclotella in April (4.2 $\mathrm{g} \mathrm{m}^{-3}$ in the middle part of L. Peipsi s.s.). However, this did not affect the dynamics of Daphnia, which had a peak in July as usual (the peak was lacking in May; biomass $0.18 \mathrm{~g} \mathrm{~m}^{-3}$ in June and $2.6 \mathrm{~g} \mathrm{~m}^{-3}$ in July - one of the highest values for the middle part). We can conclude that warm water in June is among the causes of the high abundance of Daphnia in July.

Thus, in some years the courses of the dynamics of small algae and their grazers were parallel, while in some years they were opposite. We cannot claim that a peak of filtrators always coincides with a peak or with a significant decrease in their food objects, i.e. small algae. Frequently a peak of grazers is shifted to the following month of a peak of small algae. It is possible that the step of the shift is shorter; however, sampling was not performed frequently enough to establish this. According to Matveev \& Matveeva (1997), grazing is intensive if the cladoceran to phytoplankton biomass ratio is larger than 0.1, which is the cause of the clear water phase in this case. Since the phytoplankton of L. Peipsi mainly consists of large, presumably inedible, diatoms and blue-green algae, this ratio exceeded 0.1 in only $20 \%$ of the cases, mainly in June, and mostly in the northern part of the lake. Grazing pressure was the highest in June and July 1999 accompanied with the low biomass of the food objects of grazers in June, and high in July (Fig. 3). It would be more reasonable to use the ratio of biomass of cladocerans to that of small algae (Fig. 3). Grazing pressure is far higher in the southern lake part where water temperatures and biomasses are higher than in the northern part.

It has been calculated that in L. Peipsi approximately $10 \%$ of the energy accumulated in the algae passes over to zooplankton, which means that there is a direct relationship between phytoplankton and zooplankton and an effective algal food chain (algae $\rightarrow$ zooplankton $\rightarrow$ fish) dominates (Haberman, 2001; Nõges et al., 2001). The zooplankton's food ration made up 50\% of the primary production in 1985-1986 and 34\% in 1997-1998 (Haberman, 2001; Nõges et al., 2001). Wetzel (1995) notes that utilization of more than half of the primary production is a rare phenomenon and occurs only temporarily. The amount of edible algae is the most important environmental factor affecting zooplankton (George, 2000), 

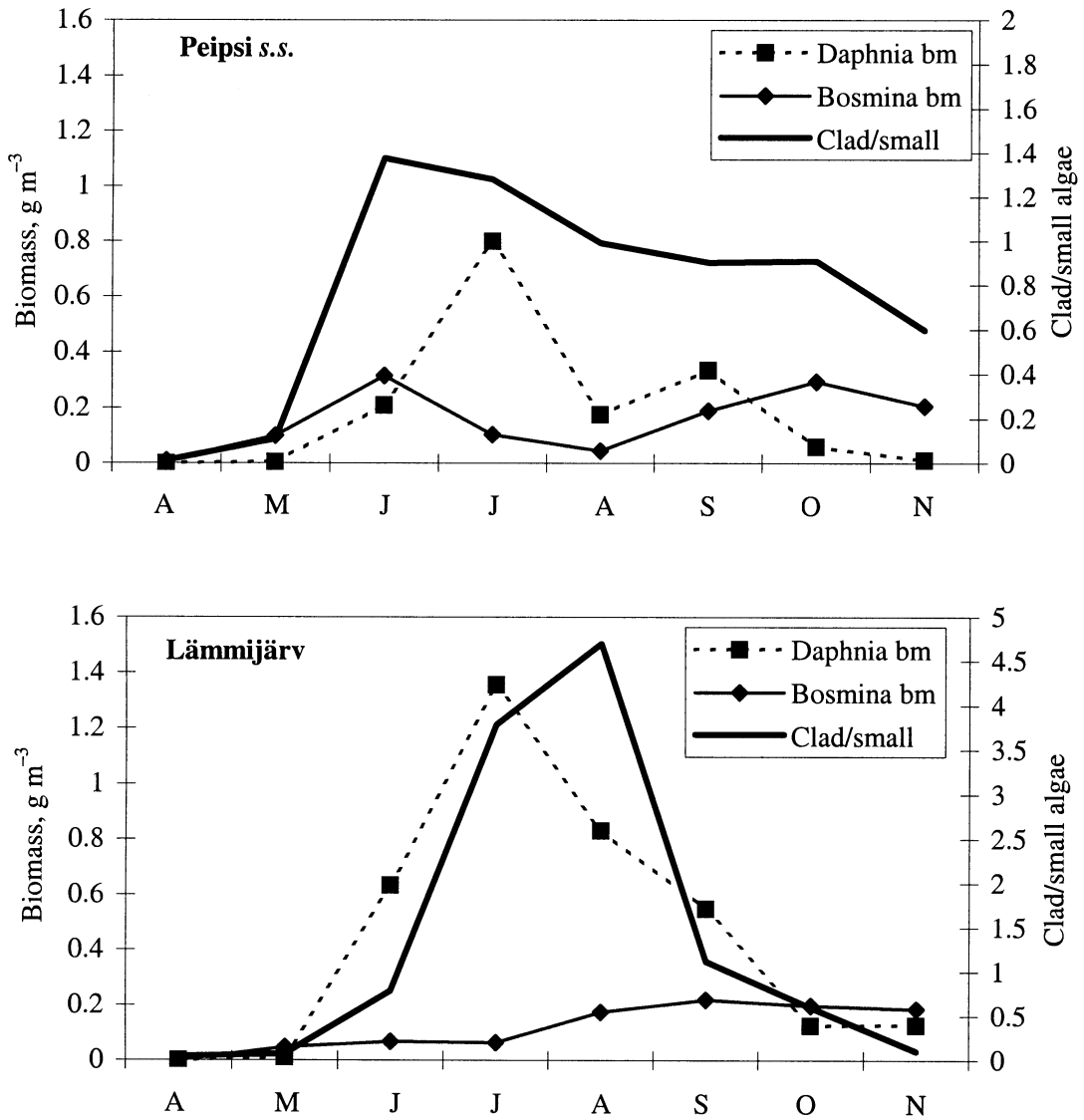

Fig. 3. Biomass of Daphnia and Bosmina and the biomass ratio of cladocerans to small algae in L. Peipsi s.s. and L. Lämmijärv, average of 1997-2003.

which is clearly associated with the trophic state of the water body. Zooplankton consums $50 \%$ of the phytoplankton production in moderately eutrophic L. Peipsi s.s. but only $12 \%$ in strongly eutrophic L. Võrtsjärv (Nõges et al., 1998; Haberman, 2003).

The biomass of copepods and, to a smaller extent, that of cladocerans behave in parallel with the biomass of small algae in spring and late autumn (OctoberNovember) but in an opposite way in summer and early autumn. The suppressive influence of the high seston content in summer, particularly in the southern parts, is likely. On the other hand, detritus concentration has had a significant inverse correlation with the production of filtrative zooplankton $(r=-0.6, P<0.01)$, which indicates the important role of zooplankton in the reduction of the concentration of dead organic matter (Nõges et al., 1993). The total biomass of filtrative zooplankton (incl. rotifers) as an average of seven years tends to behave in an opposite way to small algae whose dynamics is more fluctuating with peaks in April 
(Cyclotella), June (cryptophytes), and September (chlorophytes). The dynamics of herbivorous zooplankton coincides approximately with that of water temperature, with a maximum in the summer months (June-August) and a small peak in October.

It would be interesting to follow how a peak of Aphanizomenon affects cladocerans. Statements about the relationship of Daphnia with Aphanizomenon in the literature are controversial. Coexistence of a large amount of Aphanizomenon flos-aquae and large daphnids in a hypertrophic pond is possible (Andersson \& Cronberg, 1984). When planktivorous fish were stocked, Bosmina longirostris and rotifers replaced the daphnids, the Aphanizomenon bloom disappeared, and small algae $(<30 \mu \mathrm{m})$ flourished. According to Hambright et al. (2001), non-grazeability of Aphanizomenon allows it to gain a competitive advantage over grazeable phytoplankton. In the opinion of Komárková et al. (1995), Aphanizomenon occurred only in the presence of large daphnids, and Microcystis replaced it after large filter-feeders had been removed. According to Scheffer \& Rinaldi (2000), depending on conditions, cyanobacterial dominance can be stimulated but also suppressed by Daphnia. Daphnia can strongly limit filamentous cyanobacterial abundance (Aphanizomenon) and affect the biogeochemical cycling of nutrients (Paterson et al., 2002).

In a hypertrophic lake a high abundance of filaments was found to be always associated with Cyclops-dominated situations, low numbers were associated with Daphnia dominance, and high but rather variable numbers were associated with rotifer dominance (Jürgens \& Jeppesen, 2000). In L. Peipsi s.s. the dynamics of Daphnia and Aphanizomenon are quite different and their peaks do not coincide (June-July in the case of Daphnia, September-October in the case of Aphanizomenon). The suppressing effect of cyanobacteria, particularly Aphanizomenon and Anabaena, is obvious only in case their biomasses are very high, more than $20 \mathrm{~g} \mathrm{~m}^{-3}$. It happens seldom in the open water of L. Peipsi s.s., and lasts commonly only for a short time. Such an effect was observed in August 2002 and in October-November 2000. In this large lake zooplankton can avoid blooming patches by descending into deeper layers. In the more eutrophic southern parts, L. Lämmijärv and L. Pihkva, values higher than $20 \mathrm{~g} \mathrm{~m}^{-3}$ occur every summer; nevertheless, the biomass of Daphnia is about twice as high as in the northern part, L. Peipsi s.s (Fig. 3). The contradiction can be explained by different species compositions in different lake parts: species preferring mesotrophy and more sensitive to blue-greens and toxins play a more important role in the northern part (Bosmina berolinensis, Eudiaptomus gracilis). The species tolerating high trophy (and hence being less sensitive to blue-greens), prevail in the southern parts (D. cucullata, Bosmina c. coregoni). Another important filter-feeder among cladocerans, the genus Bosmina, is distributed quite evenly over the lake parts, although B. berolinensis is more abundant in L. Peipsi s.s. and B. coregoni in the southern parts. E. gracilis occurs irregularly and can prevail at every sampling site. Obviously, the abundance of E. gracilis is largely influenced by fish. It is among the preferred food objects of plankton-feeding fishes (smelt, vendace) in L. Peipsi (Ibneeva, 1983). 
Considering our L. Peipsi data, we can draw the following main conclusions. The years of low temperatures coincide with the low biomass of cyanobacteria and cladocerans, the years with high temperatures coincide with their high biomass. The synergistic effect of low water level and high temperature can induce a heavy water bloom formed of cyanobacteria. The autumn of the previous year seems to have an effect on the phytoplankton composition and biomass in the current year. The growth of diatoms and, to a smaller extent, also of cryptophytes and chlorophytes tends to be independent of temperature. Cladocerans are more influenced by temperature than copepods and rotifers. The biomass of copepods and, to a smaller extent, cladocerans commonly behaves in a similar way with the biomass of small algae in spring and late autumn (October-November) and in an opposite way in summer and early autumn. The suppressing effect of cyanobacteria is obvious only in the case of very heavy cyanobacterial blooms. Water temperature in spring has a stronger effect on zooplankton (particularly on cladocerans) than the temperature in autumn.

\section{ACKNOWLEDGEMENTS}

The research was supported by the Estonian target financed project SF 0362483s03. In this study the data of the Estonian State Monitoring Programme were used. We are indebted to Mrs. Ester Jaigma for revising the English text of this paper. The contribution of the anonymous referees is highly appreciated.

\section{REFERENCES}

Ahlgren, G., Hyenstrand, P., Vrede, T., Karlsson, E. \& Zetterberg, S. 2000. Nutritional quality of Scenedesmus quadricauda (Chlorophyceae) grown in different nitrogen regimes and tested on Daphnia. Verh. Internat. Verein. Limnol., 27, 1234-1238.

Andersson, G. \& Cronberg, G. 1984. Aphanizomenon flos-aquae and large Daphnia - an interesting plankton association in hypertrophic waters. In Nordisk limnologsymposium, pp. 63-76. Oslo.

Avinski, V. A., Andronikova, I. N., Letanskaya, G. I. \& Protopopova, E. V. 1995. Phytoplankton and zooplankton in lake monitoring. In Proceedings of a Workshop on Monitoring of Large Lakes (Peltonen, A. \& Viljanen, M., eds.), pp. 149-162. Joensuun Yliopisto, Joensuu.

Beaver, J. R. \& Havens, K. E. 1996. Seasonal and spatial variation in zooplankton community structure and their relation to possible controlling variables in Lake Okeechobee. Freshwater Biol., 36, 45-56.

Beisner, B. E., McCauley, E. \& Wronas, F. 1996. Temperature-mediated dynamics of planktonic food chains: the effect of an invertebrate carnivore. Freshwater Biol., 35, 219-232.

Boersma, M. \& Stelzer, C.-P. 2000. Response of a zooplankton community to the addition of unsaturated fatty acids: an enclosure study. Freshwater Biol., 45, 179-188.

Burns, C. W. 1968. The relationship between body size of filter-feeding Cladocera and the maximum size of particle ingested. Limnol. Oceanogr., 13, 675-678.

Carrick, H. J., Fahnenstiel, G. L., Stormer, E. F. \& Wetzel, R. G. 1991. The importance of zooplanktonprotozoan trophic couplings in Lake Michigan. Limnol. Oceanogr., 36, 1335-1345. 
Carvalho, L. \& Kirika, A. 2003. Changes in shallow lake functioning: response to climate change and nutrient reduction. Hydrobiologia, 506-509, 789-796.

DeMott, W. R. \& Moxter, F. 1991. Foraging on cyanobacteria by copepods: responses to chemical defences and resource abundance. Ecology, 72, 1820-1844.

Dokulil, M., Herzig, A. \& Jagsch, A. 1990. Trophic relationships in the pelagic zone of Mondsee, Austria. Hydrobiologia, 191, 199-212.

George, D. G. 2000. The impact of the regional-scale changes in the weather on the long-term dynamics of Eudiaptomus and Daphnia in Eastwaite Water, Columbia. Freshwater Biol., 45, 111-121.

Gilbert, J. J. 1994. Susceptibility of planktonic rotifers to a toxic strain of Anabaena flos-aquae. Limnol. Oceanogr., 39(6), 1286-1297.

Gilbert, J. J. \& Stemberger, R. S. 1985. Control of Keratella populations by interference competition from Daphnia. Limnol. Oceanogr., 30, 180-188.

Gophen, M. 2003. Lake Kinneret (Israel): anthropogenic changes, biological processes and water quality. In Lake Ecosystems: Biological Processes, Anthropogenic Transformation, Water Quality. Materials of International Conference II. Minsk-Naroch, pp. 90-93. Minsk.

Gulati, R. D., Bronkhorst, M. \& van Donk, E. 2001. Feeding in Daphnia galeata on Oscillatoria limnetica and on detritus derived from it. J. Plankton Res., 23(7), 705-718.

Haberman, J. 1996. Contemporary state of zooplankton in Lake Peipsi. Hydrobiologia, 338, $112-123$.

Haberman, J. 2001. Zooplankton. In Lake Peipsi. Flora and Fauna (Pihu, E. \& Haberman, J. eds.), pp. 50-68. Sulemees Publishers, Tartu.

Haberman, J. 2003. Zooplankton. In Võrtsjärv. Loodus, aeg, inimene (Haberman, J., Pihu, E. \& Raukas, A., eds.), pp. 279-299. Eesti Entsüklopeediakirjastus, Tallinn.

Haberman, J. \& Künnap, H. 2002. Mean zooplankter weight as a characteristic feature of an aquatic ecosystem. Proc. Estonian Acad. Sci. Biol. Ecol., 51, 26-44.

Haberman, J. \& Laugaste, R. 2003. On characteristics reflecting the trophic state of large and shallow Estonian lakes (L. Peipsi, L. Võrtsjärv). Hydrobiologia, 506-509, 737-744.

Haberman, J. \& Nõges, T. 2003. Cladocerans reflecting trophic state of the large Estonian lakes Peipus and Võrtsjärv. In Proceedings of the Fourth International Lake Ladoga Symposium 2002 (Simola, H., Terzhevik, A. Y., Viljanen, M. \& Holopainen, I. J., eds.), pp. 143-147. University of Joensuu, Publ. Karelian Institute, Joensuu.

Hambright, K. D., Zohary, T., Easton, J., Azoulay, B. \& Fishbein, T. 2001. Effects of zooplankton grazing and nutrients on the bloom-forming, $\mathrm{N}_{2}$-fixing cyanobacterium Aphanizomenon in Lake Kinneret. J. Plankton Res., 23(2), 165-174.

Herzig, A. 1994. Predator-prey relationships within the pelagic community of Neusiedler See. Hydrobiologia, 275/276, 81-96.

Ibneeva, N. I. 1983. Exploitation of food resources by planktophagous fishes in Lake Peipsi-Pskov. Sb. nauchn. tr. GosNIORKh, 209, 44-50 (in Russian).

Jensen, K. H. \& Larsson, P. 2000. Experimental field and laboratory tests of food search in Daphnia pulex. Verh. Internat. Verein. Limnol., 27, 1795-1802.

Jensen, J. P., Jeppesen, E. \& Olsen, R. B. 2002. Multivariate analysis of phytoplankton communities in 37 Danish lakes studied during 12 years. In Shallow Lakes. International Conference on Limnology of Shallow Lakes, Balatonfüred, Hungary. Abstracts, p. 98.Veszprém University Press.

Jeppesen, E. J., Jensen, P., Søndergaard, M. \& Lauridsen, T. 1999. Trophic dynamics in turbid and clearwater lakes with special emphasis on the role of zooplankton for water clarity. Hydrobiologia, 408/409, 217-231.

Jeppesen, E. J., Jensen, P., Søndergaard, M., Lauridsen, T. \& Landkildehus, F. 2000. Trophic structure, species richness and biodiversity in Danish lakes: changes along phosphorus gradient. Freshwater Biol., 45, 201-218. 
Jürgens, K. \& Jeppesen, E. 2000. The impact of metazooplankton on the structure of the microbial food web in a shallow, hypertrophic lake. J. Plankton Res., 22(6), 1047-1070.

Jürgens, K. \& Stolpe, G. 1995. Seasonal dynamics of crustacean zooplankton, heterotrophic nanoflagellates and bacteria in a shallow, eutrophic lake. Freshwater Biol., 33, 27-38.

Kirk, K. L. \& Gilbert, J. J. 1990. Suspended clay and the population dynamics of planktonic rotifers and cladocerans. Ecology, 71, 1741-1755.

Komárková, J., Vyhnálek, V. \& Kubečka, J. 1995. Impact of fishstock manipulation on the composition of net phytoplankton in the Římov Reservoir (Czech Republic). Water Sci. Technol., 32(4), 207-216.

Kryuchkova, N. M. 1989. Trophic Relations Between Zoo- and Phytoplankton. Nauka, Moskva (in Russian).

Kuupo-Leinikki, P., Autio, R., Hällfors, S., Kuosa, H., Kuparinen, J. \& Pajuniemi, R. 1994. Trophic interactions and carbon flow between picoplankton and protozoa in pelagic enclosures manipulated with nutrients and a top predator. Mar. Ecol. Prog. Ser., 107, 89-102.

Lampert, W. 1992. Zooplankton vertical migrations: implications for phytoplankton-zooplankton interactions. Arch. Hydrobiol., 35, 69-78.

Laugaste, R., Nõges, P., Nõges, T., Yastremskij, V. V., Milius, A. \& Ott, I. 2001. Algae. In Lake Peipsi. Flora and Fauna (Pihu, E. \& Haberman, J., eds.), pp. 31-49. Sulemees Publishers, Tartu.

Lemly, A. D. \& Dimmick, F. F. 1982. Phytoplankton communities in the littoral zone of lakes: observations on structure and dynamics in oligotrophic and eutrophic systems. Oecologia, 54, 359-369.

Makartseva, E. S. \& Trifonova, I. S. 1991. Peculiarities of seasonal functioning of zoo- and phytoplankton communities in lakes of different trophy. In Anthropogenic Changes in the Ecosystems of Small Lakes. Materials of All-Union Conference, Leningrad, 1990, pp. 297-300. Gidrometeoizdat, Sankt Peterburg (in Russian).

Matveev, V. \& Matveeva, L. 1997. Grazer control and nutrient limitation of phytoplankton biomass in two Australian reservoirs. Freshwater Biol., 38, 49-65.

Meijer, M.-L., DeBoois, I., Scheffer, M., Portielje, R. \& Hosper, H. 1999. Biomanipulation in shallow lakes in the Netherlands: an evaluation of 18 case studies. Hydrobiologia, 408/409, 13-30.

Moore, J. W., Schindler, D. E., Scheuerell, M. D., Smith, D. \& Frodge, J. 2003. Lake eutrophication at the urban fringe, Seattle Region, USA. Ambio, 32(1), 13-18.

Muck, P. \& Lampert, W. 1984. An experimental study on the importance of food conditions for the relative abundance of calanoid copepods and cladocerans. Arch. Hydrobiol. Suppl., 66, 157-179.

Muylaert, K., Declerck, S., Vyerman, W. \& De Meester, L. 2002. Biomass and community composition of phytoplankton and macrozooplankton in turbid versus clearwater shallow eutrophic lakes. In Shallow Lakes. International Conference on Limnology of Shallow Lakes. Abstracts (Padisák, J., ed.), p. 164. Veszprém University Press.

Nauwerck, A. 1963. Die Beziechungen zwischen Zooplankton und Fytoplankton im See Erken. Symb. Bot. Uppsal., 17, 5, 1-153.

Nõges, T., Haberman, J., Timm, M. \& Nõges, P. 1993. The seasonal dynamics and trophic relations of the plankton components in Lake Peipsi (Peipus). Int. Rev. Hydrobiol., 78(4), 513-519.

Nõges, T., Nõges, P., Haberman, J., Kisand, V., Kangur, K., Kangur, A. \& Järvalt, A. 1998. Food web structure in shallow eutrophic L. Võrtsjärv (Estonia). Limnologica, 28, 115-128.

Nõges, T., Haberman, J., Kisand, V., Laugaste, R. \& Zingel, P. 2001. Trophic relations and food web structure of plankton community in Lake Peipsi s.s. In Lake Peipsi. Flora and Fauna (Pihu, E. \& Haberman, J., eds.), pp. 74-81. Sulemees Publishers, Tartu.

Ogorodnikova, V. A. 1995. Zooplankton in southern Lake Ladoga: structure and abundance changes reflecting anthropogenic impact. In Abstracts of the First International Lake Ladoga 
Symposium 1993 (Simola, H., Viljanen, M., Slepukhina, T. \& Murthy, R., eds.), pp. 29-34. University of Joensuu.

Padisák, J. \& Koncsos, I. 2002. Trend and noise: long-term changes of phytoplankton in the Keszthely Basin of Lake Balaton, Hungary. Verh. Internat. Verein. Limnol., 28, 194-203.

Paterson, M. J., Findlay, D. L., Salki, A. G., Hendzel, L. L. \& Hesslein, R. H. 2002. The effects of Daphnia on nutrient stoichiometry and filamentous cyanobacteria: a mesocosm experiment in a eutrophic lake. Freshwater Biol., 47, 1217-1233.

Sartonov, A. 1995. Effects of Microcystis aeruginosa on interference competition between Daphnia pulex and Keratella cochlearis. Hydrobiologia, 307, 1-3.

Sarvala, J., Helminen, H. \& Karjalainen, J. 2000. Restoration of Finnish lakes using fish removal: changes in the chlorophyll-phosphorus relationship indicate multiple controlling mechanisms. Verh. Internat. Verein. Limnol., 27, 1473-1479.

Scheffer, M. \& Rinaldi, S. 2000. Minimal models of top-down control of phytoplankton. Freshwater Biol., 45, 265-283.

Schweizer, A. 1997. From littoral to pelagial: comparing the distribution of phytoplankton and ciliated protozoa along a transect. J. Plankton Res., 19(7), 829-848.

Smith, A. D. \& Gilbert, J. J. 1995. Relative susceptibility of rotifers and cladocerans to Microcystis aeruginosa. Arch. Hydrobiol., 132, 309-336.

Sommer, U. 1989. Nutrient status and nutrient competition of phytoplankton in a shallow, hypertrophic lake. Limnol. Oceanogr., 34(7), 1162-1173.

Tanner, R., Kangur, K., Spoof, L. \& Meriluoto, J. 2005. Hepatotoxic cyanobacterial peptides in Estonian fresh water bodies and inshore marine water. Proc. Estonian Acad. Sci. Biol. Ecol., $\mathbf{5 4}, 40-52$.

Taylor, W. D. \& Johannson, O. E. 1991. A comparison of estimates of productivity and consumption by zooplankton for planktonic ciliates in Lake Ontario. J. Plankton Res., 13, 363-372.

Telesh, I. V. 1995. Rotifer assemblages in the Neva Bay, Russia: principles of formation, present state and perspectives. Hydrobiologia, 313/314, 57-62.

Wetzel, R. G. 1995. Death, detritus and energy flow in aquatic ecosystems. Freshwater Biol., 33, 83-89.

Wetzel, R. G. \& Likens, G. E. 1991. Limnological Analyses. Springer Verlag, New York.

Wickham, S. A. \& Gilbert, J. J. 1993. The comparative importance of competition and predation by Daphnia on ciliated protists. Arch. Hydrobiol., 126, 289-313.

Wolfinbarger, W. C. 1999. Influences of biotic and abiotic factors on seasonal succession of zooplankton in Hugo Reservoir, Oklahoma, U.S.A. Hydrobiologia, 400, 13-31.

Zingel, P. 2003. Planktilised ripsloomad. In Võrtsjärv. Loodus, aeg, inimene (Haberman, J., Pihu, E. \& Raukas, A., eds.), pp. 301-310. Eesti Entsüklopeediakirjastus, Tallinn.

\title{
Zoo- ja fütoplanktoni sesoonsus Peipsi järves kui veetemperatuuri funktsioon
}

\author{
Reet Laugaste ja Juta Haberman
}

Zoo- ja fütoplanktoni ning veetemperatuuri sesoonset dünaamikat seirati mõõdukalt eutroofses Peipsi järves vegetatsiooniperioodil aastail 1997-2003. Zooplanktonile söödava väikesemõõdulise (alla 40-mikromeetrise diameetriga) fütoplanktoni dünaamikat kõrvutati selle peamiste tarvitajate - kopepoodide ja kladotseeride omaga. Kladotseeride ja sinivetikate (tsüanobakterite) madal biomass langes kokku 
jaheda vegetatsiooniperioodiga ja kõrge biomass soojaga. Madala veetaseme ja kõrge veetemperatuuri sünergiline efekt tõi kaasa väga intensiivse sinivetikate põhjustatud veeõitsengu. Tavalisest soojem hilissügis mõjutab fütoplanktoni arengut ja koosseisu järgmise aasta kevadel. Ränivetikad, vähemal määral ka rohe- ja neelvetikad, on veetemperatuurist vähe sõltuvad; kladotseerid on temperatuurist rohkem mõjutatud kui kopepoodid ja keriloomad. Kopepoodide, vähemal määral ka kladotseeride dünaamika kulgeb paralleelselt väikeste vetikate omaga kevadel ja hilissügisel, vastupidiselt suvel ja varasügisel. Sinivetikate allasuruv mõju zooplanktonile ilmneb vaid väga tugeva veeõitsengu puhul. Kevadise veetemperatuuri mõju zooplanktonile, eriti kladotseeridele, on tugevam kui sügisese oma. Kokkuvõttena on veetemperatuuril zoo- ja fütoplanktoni dünaamikale suur mõju. 